\title{
A HISTORICAL REVIEW OF THE BRONTOTHERIIDAE COLLECTED IN SASKATCHEWAN
}

TIM TOKARYK, Earth Sciences, Saskatchewan Museum of Natural History, Wascana Park, Regina, Saskatchewan. S4P 3V7

Brontothere (Mammalia: Perissodactylia) material has been recorded from Saskatchewan since the late 1800 's. This review of the literature details their discovery.

\section{Introduction}

The progressive history of fossil vertebrate collecting in Saskatchewan can be dated back to the 1880's when R.G. McConnell and T.C. Weston collected a small sample of Tertiary fossils from the Cypress Hills area. Although the Tertiary deposits are rich in vertebrate material (Late Paleocene, Late Eocene, Early Oligocene, Middle Miocene), the Mesozoic deposits are also quite respectable (Upper Cretaceous: the terrestrial Frenchman Formation and the marine Bearpaw Formation) which gives Saskatchewan a diverse range of fossil vertebrates.

The late Eocene and Early Oligocene beds of Saskatchewan yield many vertebrate fossils such as Cupressimus barbarae, ${ }^{10}$ a new species of rodent known only from this province, and mammals belonging to the extinct order of Multituberculata such as Ectypodus lovei. ${ }^{2} 11$ However, of the larger vertebrates of those times, only one stands out, the brontothere.

These large herbivorous mammals (some standing 7 feet at the shoulders) roamed Saskatchewan 35-42 million years ago, browsing mostly in forest and associated plant life. The forests were important for these mammals to survive, but they may have contributed to their demise. Russell concluded "that the disappearance of the brontotheres is analogous to that of the dinosaurs, although operating on a shorter time interval. The regional uplift that occurred in western North America at the close of Eocene time began a climatic change toward less humid, and less tropical climate, providing conditions suitable for the spread of grasslands at the expense of forests,..." where brontotheres found their food. "The brontotheres reached the end of the blind alley into which their restricted feeding habits and the changing climatic and plant environment had directed them." 8

One of the most unusual anatomical aspects of brontotheres was their large horns on either side of the nasal. These varied considerably in size and shape which has contributed some confusion to the taxonomy.

\section{Brontotheres from Saskatchewan}

E. D. Cope's description of McConnell and Weston's collection included fossil fish, reptiles and large numbers of mammals. ${ }^{1}$ Cope refered most of the brontothere material to Menodus on the basis of partial skulls, dentaries and several postcranial elements.

Later, Lawrence Lambe, then vertebrate palaeontologist with the Geological Survey of Canada, described a collection made mostly by himself in 1904, in which he "examined the exposure of the Oligocene deposits along the eastern escarpment of the Cypress Hills. The greatest part of the collection was made in Bone Coulee and its numerous tributary coulees, and in its southern extension for a few miles along 
Fairwell Creek." 3 Lambe listed all of his brontothere specimens as Megacerops, based mostly on dental material.

In 1934, when Loris Russell was with the National Museums of Canada, he reviewed the Lower Oligocene vertebrate fauna of the Cypress Hills and identified several species of brontotheres, but modestly remarked that he had followed "the classification of Osborn, although aware that some students of this family do not accept all of the genera and species recognized by that author. However, the writer is not qualified by experience to decide in this matter, and for sake of uniformity, has used Osborn's groups." 5 The five genera that were described were Teleodus, Brontops, Allops?, Menodus and Megacerops, based on skulls and dental material.

When Russell reviewed the brontotheres from the Cypress Hills of Saskatchewan, he cited only two genera, Brontops and Megacerops, using excellent skulls. ${ }^{6}$

The majority of brontothere skulls that were collected from the Cypress Hills area were recorded from an area called the Hunter Quarry. While collecting fossils in this area for the G.S.C. in 1936 Mr. and Mrs. Fenley Hunter of Flushing, New York and Albert Silberling of Harlowton, Montana, located a large area of fossiliferous beds. These beds have contained many fine brontothere specimens along with other mammalian remains and have been worked by several institutions including the Royal Ontario Museum, National Museums of Canada and the Saskatchewan Museum of Natural History.

Even though the Hunter Quarry is considered Early Oligocene on the geological time scale, a few specimens of brontotheres have been collected from the Late Eocene of Saskatchewan. In reviews of the Eocene fauna a right $\mathrm{P}^{4}$ [fourth premolar] was described as Diplacodon sp., a Late Eocene brontothere. ${ }^{9} 7$ Storer, in reviewing the same fauna with more specimens, conclud- ed "with such poor material, I feel that even generic identification is unwarranted." 11

Spencer Lucas and Robert Schoch described a new genus of brontotheres from the Late Eocene of western North America which they called Duchesneodus based on lower jaws. Duchesneodus includes most Late Eocene species formerly referred to Teleodus, one of which is found in Saskatchewan.

Nearly all the material from the Tertiary beds of Saskatchewan is disarticulated. However, in 1973 the staff of S.M.N.H. collected a skeleton, $60 \%$ complete, which is a first for Canada as noted by Tillie. ${ }^{12}$ This bronto is tentatively referred to as Megacerops (P1349.1). This skeleton consists of a complete skull (fig. 1), vertebral column (cervical and dorsal), nearly all the ribs and one complete and one semicomplete front limb. In general the specimen is missing the hind section.

The author spent a month at the Tyrell Museum of Palaeontology in Drumheller, Alberta, gaining experience with new mounting techniques. The staff there reconstructed the missing bones of the brontothere with much patience and expertise, and an agreement was made between the two institutions that we would send the molds of the specimen to them and they would make the casts. Later, the author joined them to mount as many replicas as time allowed. Casts for four skeletons were made. Two were to stay in Drumheller and two were to come to the Museum of Natural History in Regina. However, because of the lack of space in the museum neither of the brontothere skeletons will be mounted until space is made available (one will eventually be mounted and sent to the Eastend Museum, Eastend, Saskatchewan).

\section{Discussion}

Russell stated in 1934 that brontothere classification was somewhat in doubt; since then, more doubt has clouded the taxonomy with new specimens being 


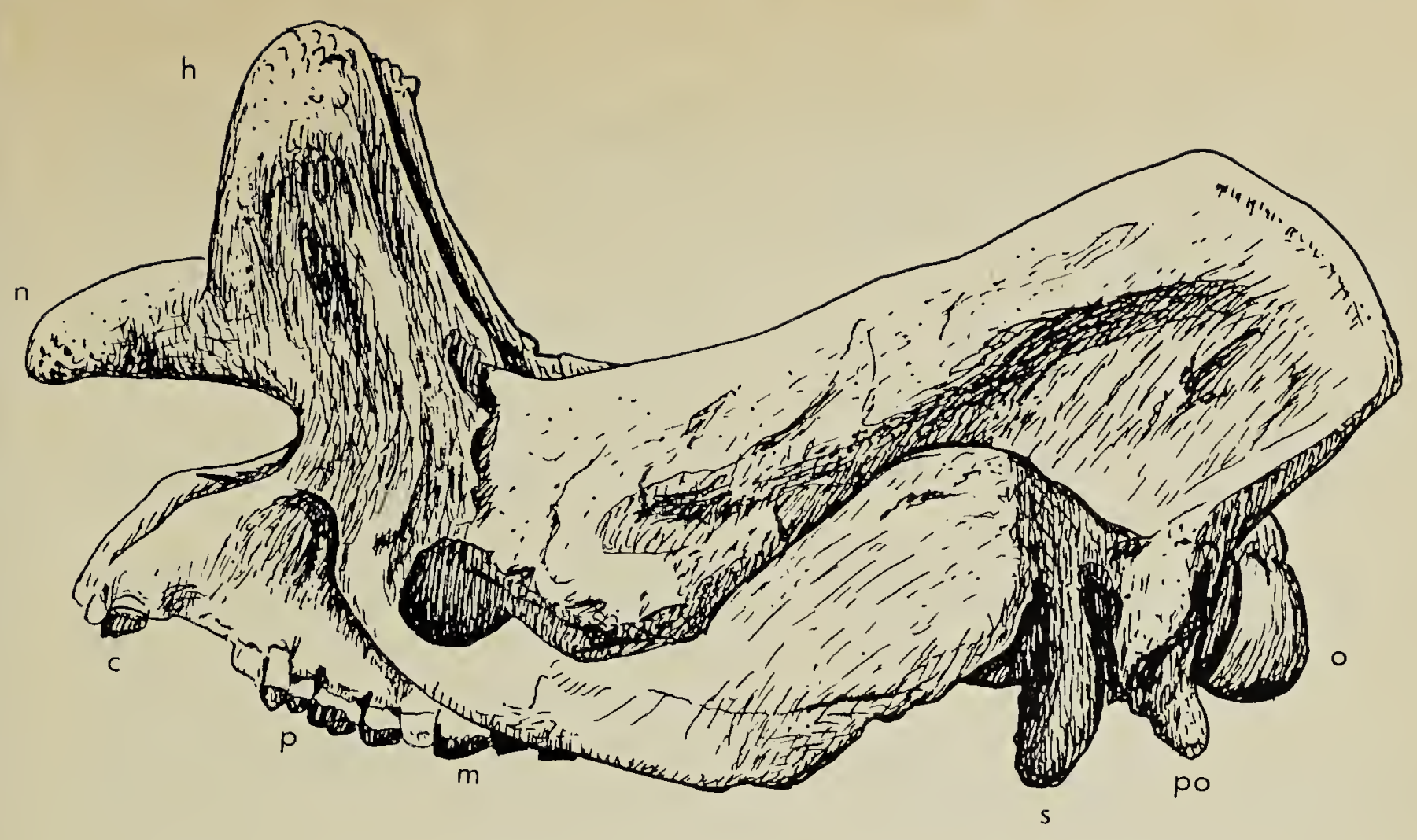

Figure 1. SMNH P1349.1, Megacerops?, left lateral view. Scale is equal to $10 \mathrm{~cm} . \mathrm{c}$ canine tooth, h horn, $m$ molar teeth, $n$ nasal, o occipital, p premolar teeth, po paraoccipital, s squamosal. Illustration prepared by Fred Lahrman (SMNH).

recovered. Genera and species of brontotheres are generally defined using characteristics of the teeth and horns. Since mammalian teeth are usually diagnostic it should not be too difficult to classify brontotheres. However, the dentaries are usually very worn in adult specimens making identification sometimes impossible. Some brontotheres can however be identified by the number of incisors. Problems also arise in identifying brontotheres according to their horns since they vary enough to imply that this is the result of sexual dimorphism and/or individual variation. The skull alone cannot be the only diagnostic tool.

The Saskatchewan Museum of Natural History has over half a dozen skulls of brontotheres in its collections and displays including a small juvenile skull with budding horns. Most have come from the Hunter Quarry (Calf Creek Local Fauna) or from
Pine Cree Regional Park (Southfork Local Fauna) It is to be hoped that in the near future a better study can review this family which includes many Saskatchewan specimens.

1 COPE, E.D. 1891 On vertebrata from the Tertiary and Cretaceous Rocks of the North West Territory. Contr. to Can. Palaeo., Geol. Surv. of Can., Vol. 3.

2 KRISHTALKA, L., R.J. EMRY, J.E. STORER and J.F. SUTTON 1982 Oligocene multituberculates (Mammalia: Allotheria): youngest known record. 1. of Paleo. 56(3):791-794.

${ }^{3}$ LAMBE, L. 1908 The Vertebrata of the Oligocene of the Cypress Hills, Saskatchewan. Contr. to Can. Palaeo. 3(4). 
4. LUCAS, S.G. and R.M. SCHOCH 1982 Duchesneodus, a new name for some titanotheres (Perissodactyla: Brontotheriidae) from the Late Eocene of western North America. J. of Paleo. 56(4):1018-1023.

5 RUSSELL, L. 1934 Revision of the Lower Oligocene Vertebrate Fauna of the Cypress Hills, Saskatchewan. Trans. of the Roy. Can. Inst. 20:49-67, plates.

6 RUSSELL, L. 1940 Titanotheres from the Lower Oligocene Cypress Hills Formation of Saskatchesan. Trans. of the Roy. Soc. of Can. Sec. 4, 34:89-100, plates.

7 RUSSELL, L. 1965 Tertiary Mammals of Saskatchewan Part I: The Eocene Fauna. Roy. Ont. Mus., Life Sci. Contr. 67.
${ }^{8}$ RUSSELL, L. 1973 Geological evidence on the extinction of some large terrestrial vertebrates. Can. J. Earth Sci. 10(2):140-145.

${ }^{9}$ RUSSELL, L. and R.T. WICKENDEN D1, 1933 An Upper Eocene vertebrate fauna from Saskatchewan. Trans. of the Roy. Soc. of Can. Sec. 4, 3rd Series, 27:53-65.

10 STORER, J. 1978 Rodents of the Calf Creek Local Fauna. Nat. Hist. Contr. 1:1-54.

1 STORER, J. 1984 Mammals of the Swift Current Creek Local Fauna. Nat. Hist. Contr. 7:1-158.

12 TILLIE, R. 1973 A fossil first for Canada. Blue Jay $31(4): 242-243$.

\section{VOLUNTEERS WANTED TO PRESENT WINTER INTERPRETIVE PROGRAMS}

The Saskatchewan Natural History Society has tentatively agreed to present five interpretive programs this winter in Saskatchewan's Provincial Parks. The programs will be offered through a cooperative agreement with Saskatchewan Parks and Renewable Resources and the Society.

Volunteers are required from the SNHS to present one program in Cypress Hills, Greenwater and Moose Mountain Provincial Parks and two programs in Duck Mountain Provincial Park for a total of five programs. Program dates are to be determined, but may be offered in conjunction with festival events occurring on weekends in the parks.

Programs should include a Saturday evening indoor presentation followed by a walk, ski or snowshoe the following day. Content should be appropriate for a winter park environment. Past programs have covered topics from wildlife in winter to snow facts. Program materials, i.e. audio visual equipment, props and snowshoes may be requested for loan from Saskatchewan Parks and Renewable Resources.

S.P.R.R. will be providing the society with an honorarium of a set amount for each weekend event.

If you are interested in volunteering your time to share the magic of winter with others contact: Lin Gallagher, 2920 Argyle Street, Regina, Saskatchewan S4S 2A9 or telephone: home 584-0696, office 787-2327. 